\title{
Seasonal and Regional Variability of Physicochemical and Agronomic Characteristics of Sewage Sludge
}

\author{
Bülent Topcuoğlu*, M. Kubilay Önal, Nuri Arı and Muharrem Certel
}

\begin{abstract}
Sewage sludge (sludge) samples were monthly sampled in one-year duration from ten high sized wastewater treatment plant in the coastal regions of Antalya, Turkey. Water content, $\mathrm{pH}$ and conductivity degree, organic matter level, total $\mathrm{N}$, exchangeable $\mathrm{K}, \mathrm{Ca}, \mathrm{Mg}$ and $\mathrm{Na}$, total and available $\mathrm{P}, \mathrm{Fe}, \mathrm{Mn}, \mathrm{Zn}$, $\mathrm{Cu}, \mathrm{Ni}, \mathrm{Pb}, \mathrm{Cd}$ and $\mathrm{Cr}$ concentrations in sludge samples were determined, and were evaluated with regard to sampling region and the sampling season. All analyse parameters, especially conductivity, $\mathrm{N}, \mathrm{P}$ and heavy metal contents and their extractable forms in sludge of all regions were found higher as compared with the conventional manure. The parameters studied in sludge samples were significantly changed depending on the sampling region and the sampling season. Total heavy metal contents in sludge samples were determined below the regulation limits, but available fractions of metals were determined very high for $\mathrm{Zn}$ and $\mathrm{Mn}$. Generally conductivity, total organic matter, total $\mathrm{N}$ and $\mathrm{P}$ contents of sludge samples were determined at high levels in summer and autumn seasons, whereas total $\mathrm{Mn}, \mathrm{Ni}, \mathrm{Cd}$ and $\mathrm{Cr}$ contents of sludge samples were low in these seasons. With regard to agronomic properties, sludges have a slightly acidic reaction and high organic matter and $\mathrm{N}$ and $\mathrm{P}$ contents. However, high conductivity value and high metal bioavailability are considered as limiting factors for the agricultural use of sludge.
\end{abstract}

Index Terms- Sludge, Physicochemical Characteristics, Heavy Metals, Seasonal Variations

\section{INTRODUCTION}

Due to the population growth the amount of sludge produced as a result of wastewater treatment increases and millions of tons of residual sludges worldwide every year are generated. That brings the challenges to its proper management. The basic disposal methods for such large quantities of sludge are land application, landfilling, incineration, ocean dumping and lagooning [1]. The disposal of sludge in landfills or by incineration is a feasible option but both these strategies are expensive and may cause environmental problems. Compared to this, the utilization of sludge for agricultural use is the best alternative way for sludge disposal because it recycles both nutrients and organic matter. It has been reported that the plant nutrient composition of the sludge is similar to organic waste-based soil conditioners routinely applied to agricultural areas such as manure and compost [2].
However, using sludge as fertilizer can represent a potential threat to the environment because of the possible high heavy metal and toxic compound contents, a problem that can be aggravated if the toxic metals are mobilized in soil to be taken up by plants or transported in drinking water.

Total concentration and different forms of heavy metals vary widely according to the nature of the individual metal and the physico-chemical processes involved in sludge wastewater treatment [3]. Depending on the type of the treatment, aerobic or anaerobic, the chemical composition of the sludge, $\mathrm{pH}$, temperature, redox potential, and initial speciation of the metals, metals can undergo different processes: a) re-solubilization at low $\mathrm{pH}$; b) complexation by ammonium, organics from transformation of volatile substances; c) precipitation as sulphurs or hydroxides and carbonates; d) adsorption on sludge particles. In aerobic digestion, oxidation usually takes place, usually of the reducible metal fraction, which increases the total residual metal fraction [4]. Significant differences in physicochemical properties and total metal concentrations of sludges taken from different regions are found, and various sludges differ according to each parameter, which are explained by the difference in the sources of sludge and treatment type and efficiency [5]. Sludge composition is also determined by the kind of effluents discharged into sewers. Sewerage systems with industrial discharges will give rise to sludges differing markedly in composition with time depending on the industrial activities, weather and other factorsand heavy metal composition of sludges can be extremely variable [6].

Antalya region of Turkey have a high economic potential, familiar with tourism, agriculture and industrial activities for all season. Especially in the high tourism season population may rise over 5 millions and major industrial, tourism and agricultural activities vary from one site to another. Due to high variability of the tourism, industrial and and agricultural activities of Antalya, various characteristics and quantities of sludge are generated by wastewater treatment plants.

The objective of this paper is to determine the seasonal and regional variabilities on the agronomic and physicochemical characteristics of sludges for agricultural utilization.

\footnotetext{
*Akdeniz University, Antalya
} 


\section{MATERIAL AND METHODS}

\section{A. Study Area and Sampling of Sludge}

Sludge samples were monthly collected from ten treatment plants located at coastal areas of Antalya, namely: Tekirova, Beldibi, Göynük, Çamyuva, Kemer, Antalya-Hurma, Serik, Belek, Side and Alanya during one year (Figure 1). All of the treatment plants receive domestic and a little amount of industrial effluents and have aerobic biological treatment units. Sludge samples were directly collected from belt filtered raw material before disinfection, lime stabilization or thermal microbial stabilization processes from the treatment plant.

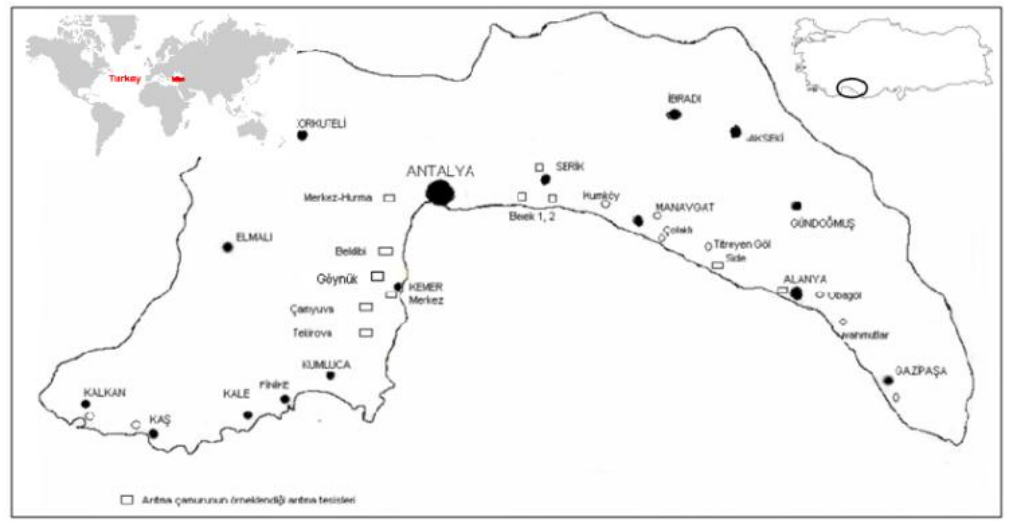

Fig 1. Big and middle sized biological wastewater treatment plants located at the coastal regions of Antalya

\section{RESULTS AND DİSCUSSION}

\section{B. Sample Preparation and Sludge Analysis}

After a moisture analysis, the sludge samples were ovendried at $65{ }^{\circ} \mathrm{C}$ to avoid microbial development. The material was mixed, ground and passed through a $1 \mathrm{~mm}$ sieve, eliminating stones, roots and fragments of plastic and metal. The final material was stored in plastic bottles at room temperatures until analysis. Three replicates of each dried sample were analyzed for several physicochemical and elemental variables.

In sludge samples $\mathrm{pH}$, total organic matter (OM), electrical conductivity (EC) kjeldahl nitrogen (N) were analysed by using standard methods [7]. In sludge samples available phosphorus [8], exchangeable $\mathrm{Na}, \mathrm{K}, \mathrm{Ca}$ and $\mathrm{Mg}$ [9], total and DTPA extractable $\mathrm{Fe}, \mathrm{Mn}, \mathrm{Zn}, \mathrm{Cu}, \mathrm{Ni}, \mathrm{Pb}, \mathrm{Cd}$ and $\mathrm{Cr}$ were analysed. For the determination of 'total' heavy metal concentrations, sludge samples were digested in aqua regia $\left(1: 3 \quad \mathrm{HNO}_{3} / \mathrm{HCl}\right)$ according to the international standard [10]. Bioavailable fractions (DTPAextractable) of metals were extracted from soil with diethylenetriaminepentaacetic acid-CaCl2-triethanolamine adjusted to $\mathrm{pH} 7,3$ [11]. Total and bioavailable metal concentrations of sludge samples were analysed using ICPMS under optimised measurement conditions, and values were adjusted for oven dried $\left(12 \mathrm{~h}\right.$ at $\left.105^{\circ} \mathrm{C}\right)$ material.

Analysis of variance was used to evaluate the effects of different factors. Statistical analyses were performed by using SPSS-16 for Windows program.

\section{A. The physicochemical properties and metal contents of sludges}

Some physicochemical properties of sludge samples and variation of total and available heavy metal contents and their relative availabilities from ten wastewater treatment plants were presented in Table 1, Table $2 \mathrm{a}$ and Table $2 \mathrm{~b}$. The data and significance of the change of examined criteria in the sampling regions in the relevant Tables are given together. In order to compare the physical and chemical composition of sludge, some physical and chemical properties and some metal contents of manure, municipal solid waste compost (MSWC) and spent mushroom compost (SMC) were also presented in these Tables.

The moisture contents of the sludge varied between 79-88\% according to the month, but no statistical difference was found. Since the water content in the sludge depends on the operation performance of the treatment plant equipment, this criterion is evaluated as treatment plant operation performance rather than the sludge characterization.

Variation in $\mathrm{pH}, \mathrm{EC}$, organic matter, total $\mathrm{N}, \mathrm{P}$, exchangeable $\mathrm{K}, \mathrm{Ca}$, Na parameters of sludges among the treatment plants were found statistically important. All sludges produced in treatment plants have acidic and slightly acidic reaction ranged from 5,99 to 6,87. EC values showed a big variation among the sludges, ranged between 4.28-8.61 dS $\mathrm{m}^{-1}$. All sludges had high EC values, which indicated a high salt content above the critical level $4 \mathrm{dS} \mathrm{m}^{-1}$ [12]. High EC values would likely be the soluble salts responsible for the high salinity. In the tourism regions seawater is being used for toilet flushing in Antalya, which can explain the high salt contents of sludge. It has been reported that the sludge can cause soil salinity due to its high conductivity value, which leads to an increase in the availability of certain metals and thus cause toxic accumulation of heavy metals during long- 
term sludge application to the soil $[13,14,15]$. Sludges showed a big exremity with regard to organic matter and total nitrogen content. However all sludges have a high rate of organic matter above $50 \%$. Total and available $\mathrm{P}$ rates were found generally higher in sludge for an organic matter source. Among the sludges of treatment plants, the lowest rate of total and available $\mathrm{P}$ and exchangeable $\mathrm{K}, \mathrm{Ca}$, It is seen that the concentration of metals in sludge has below the relevant limit values of total $\mathrm{Zn}, \mathrm{Cu}, \mathrm{Ni}, \mathrm{Pb}, \mathrm{Cd}$ and $\mathrm{Cr}$ contents when compared with the limit values of sludge. Total and DTPAextractable heavy metal contents of sludge were found to be quite high as compared with conventional manure used in organic matter fertilization of soils (Table 2a, Table 2b). Total $\mathrm{Cu}, \mathrm{Ni}, \mathrm{Pb}$ and $\mathrm{Cd}$ contents of sludge were found to be quite high as compared with conventional manure, MSWC and SMC used as organic matter in the soil amendments. Zn content of sludge was similar to MSWC. According to soil pollution criteria, it seems that all sludges could be used for agronomic purposes in soil amendments without pollution risks.

The ratio of DTPA extractable concentration to the total metal concentration is defined as the 'relative availability' of metals [16]. It is seen that there are significant differences between the relative availability of heavy metals examined in this respect (Table 2a, Table 2b). $\mathrm{Zn}$ was found at the highest rate of relative availability, 50-60\%. It has been reported that heavy metals in sludges may be more mobile than earth's natural metals due to their high extractability [17]. Although permissible concentrations of heavy metals in sludge are based on total concentration, the bioaccumulative metal concentration in terms of environmental impact is more important [18]. It has been reported that determination of extractable concentrations as well as total concentrations of $\mathrm{Mg}$ and $\mathrm{Na}$ were genereally determined in Alanya and Serik sludges. With regard to agronomic properties, sludge has a low $\mathrm{pH}$ degree and high organic matter and $\mathrm{N}$ and $\mathrm{P}$ contents and lower $\mathrm{K}$ content than cattle manure. EC value of sludge is similar to MSWC. Nitrogen and P have been reported as the most abundant essential plant nutrients in the treatment sludge for the development of higher plants [19]. As can be seen from the examination of Table 1, although the contents of organic matter, $\mathrm{N}$ and $\mathrm{P}$ in sludge are generally highand accepted as an important macronutrient source, high conductivity value of sludge is considered as limiting factors in agricultural utilization of sludge.

TABLE 1: THE PHYSICOCHEMICAL AND AGRONOMIC PROPERTIES OF SLUDGES

\begin{tabular}{|c|c|c|c|c|c|c|c|c|c|c|c|}
\hline \multirow{2}{*}{ Bölge } & Nem & $\mathrm{pH}$ & $\mathrm{EC}$ & $\mathrm{OM}$ & Total N & Available P & Total P & $\mathrm{K}$ & $\mathrm{Ca}$ & $\mathrm{Mg}$ & $\mathrm{Na}$ \\
\hline & $\%$ & & $\mathrm{dS} \mathrm{m}^{-1}$ & \multicolumn{4}{|c|}{$\%$} & \multicolumn{4}{|c|}{ Exchangeable fraction, $\mathrm{mg} \mathrm{kg}^{-1}$} \\
\hline Tekirova & 84 & 6,26 & 8,05 & 75 & 6,05 & 0,179 & 1,334 & 2902 & 5467 & 2038 & 3050 \\
\hline Göynük & 81 & 6,06 & 6,54 & 83 & 7,29 & 0,153 & 1,497 & 4483 & 6485 & 1351 & 1056 \\
\hline Kemer & 79 & 6,30 & 6,92 & 71 & 5,95 & 0,157 & 1,306 & 3133 & 5319 & 1217 & 857 \\
\hline Beldibi & 86 & 5,99 & 8,61 & 81 & 6,71 & 0,183 & 1,479 & 4089 & 5977 & 1598 & 1270 \\
\hline Antalya & 85 & 6,29 & 5,93 & 65 & 4,96 & 0,166 & 1,454 & 3728 & 6061 & 1294 & 611 \\
\hline Çamyuva & 82 & 6,18 & 8,29 & 76 & 6,12 & 0,229 & 1,830 & 5796 & 6892 & 1683 & 1292 \\
\hline Serik & 84 & 6,58 & 4,28 & 52 & 3,73 & 0,112 & 0,826 & 1285 & 5050 & 1410 & 473 \\
\hline Belek & 88 & 6,43 & 7,67 & 77 & 6,71 & 0,200 & 1,281 & 3634 & 5654 & 1362 & 1056 \\
\hline Side & 79 & 6,11 & 7,59 & 77 & 7,14 & 0,150 & 1,374 & 3818 & 5542 & 1440 & 1055 \\
\hline Alanya & 68 & 6,87 & 5,64 & 51 & 3,61 & 0,160 & 1,197 & 730 & 5917 & 1290 & 455 \\
\hline Significancy & öd & **** & $* * *$ & $* * *$ & $* * *$ & * & ** & $* * *$ & ** & öd & $* *$ \\
\hline Manure $^{1}$ & 54 & 7,96 & 4,8 & 73,8 & 2,12 & 0,16 & 1,77 & 15600 & & & \\
\hline MSWC $^{1}$ & 35,4 & 7,66 & 8,88 & 51,5 & 1,15 & 0,12 & 0,77 & 550 & & & \\
\hline SMC $^{1}$ & 61 & 6,63 & 7,15 & 64,8 & 2,80 & 0,08 & 0,35 & 340 & & & \\
\hline
\end{tabular}

*: $\mathrm{P}<0.05, * *: \mathrm{P}<0.01, * * *: \mathrm{P}<0.001$. ns: not significant; ${ }^{1}$ : [20].

heavy metals is important in determining the likely effects of plant product and metal uptake and in establishing soil quality criteria [21]. It is reported that due to high mobility and potential bioavailability of heavy metals, sludge can not be used in agriculture [22]. Total concentrations of heavy metals in sludge and the soil $\mathrm{pH}$ can not be a sufficient criterion to control the metal accumulation in the vegetation that the different fractions of heavy metals in the wastes have more environmental significance than the total concentration [23].

Relative availability values of the elements investigated according to the data were generally in the order of $\mathrm{Zn}>\mathrm{Mn}>$ $\mathrm{Ni}>\mathrm{Fe}>\mathrm{Cu}>\mathrm{Cd}>\mathrm{Pb}>\mathrm{Cr}$. It is reported that the repeated applications of sludge to the greenhouse soil caused the following accumulation order of DTPA-extractable heavy metals in the soil; $\mathrm{Zn}>\mathrm{Pb}>\mathrm{Cu}>\mathrm{Ni}>\mathrm{Cd}$ [20].. According to the results of collective research conducted in Europe, the accumulation of bioavailable heavy metals in the soil by sludge application was in the following order; $\mathrm{Zn}>\mathrm{Cu}>\mathrm{Pb}>$ $\mathrm{Cd}>\mathrm{Ni}>\mathrm{Cr}$ [24]. According to this, it is understood that $\mathrm{Zn}$ is dominant heavy metal in sludge and it causes the highest bioavailable accumulation in the soil. Although total $\mathrm{Zn}$ concentration of sludge was found to be below the limit values, high relative availability of the available fraction of $\mathrm{Zn}$ is considered to be an important factor to be taken into consideration for the agricultural use of the sludge when the regulation values are set. 
TABLE IIA: TOTAL AND DTPA-EXTRACTABLE METALS OF SLUDGES

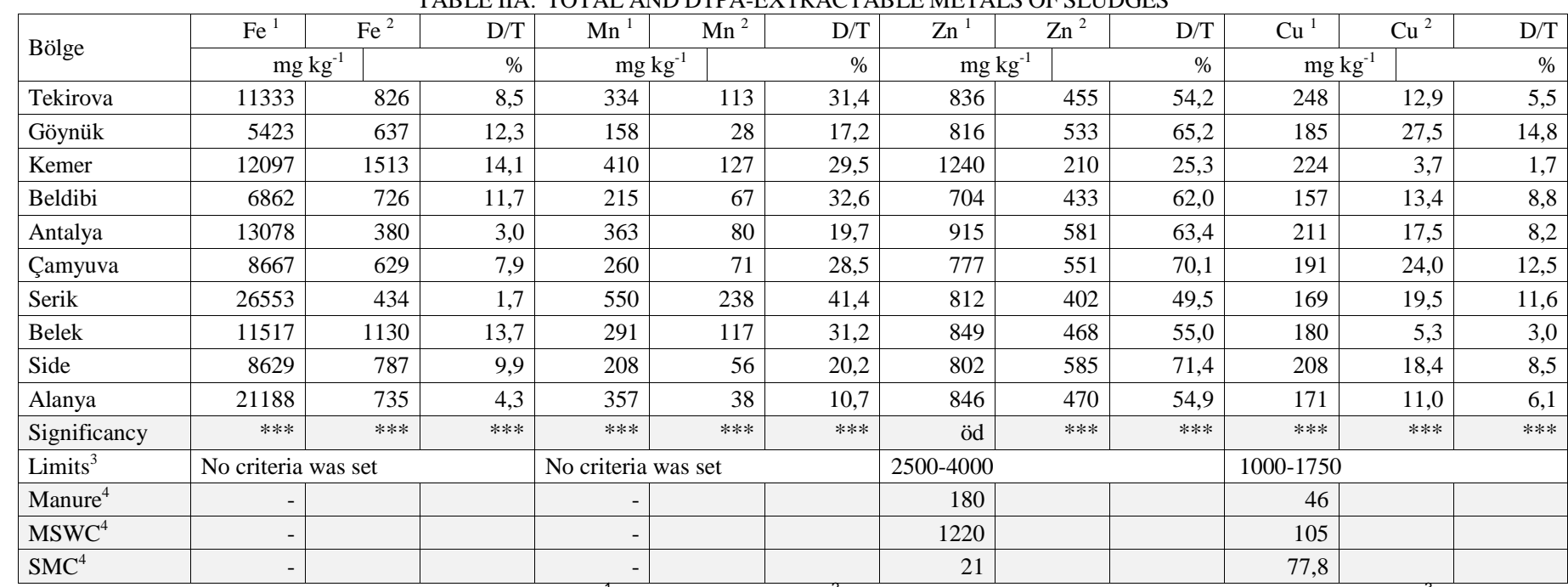

${ }^{*}: \mathrm{P}<0.05,{ }^{* *}: \mathrm{P}<0.01,{ }^{* * \star}: \mathrm{P}<0.001$. ns: not significant, ${ }^{1}:$ total concentration, ${ }^{2}$ : extractable concentration; D/T: 'DTPA/Total rate (\%); ${ }^{3}:$ Limit values, mg kg-1 dry wt (CEC, 1986); ${ }^{4}:[25]$.

TABLE IIB: TOTAL AND DTPA-EXTRACTABLE METALS OF SLUDGES

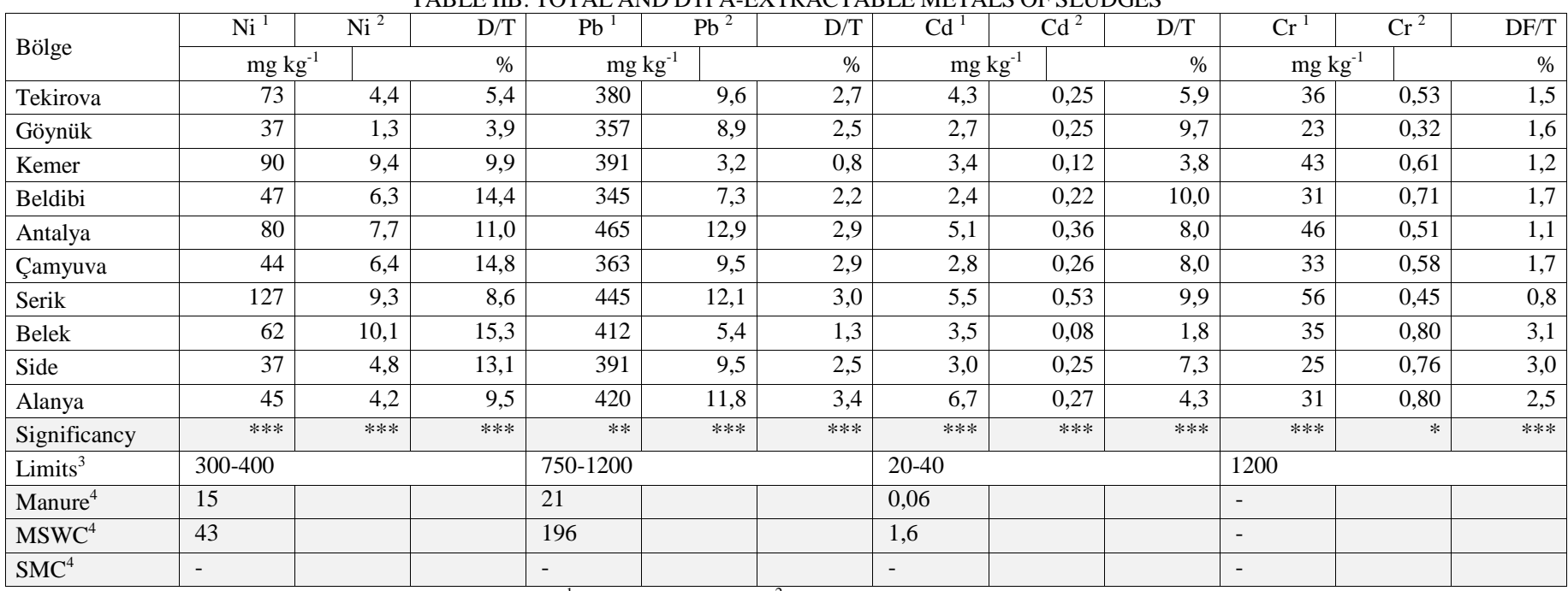

*: $\mathrm{P}<0.05, * *: \mathrm{P}<0.01, * * *: \mathrm{P}<0.001$. ns: not significant, ${ }^{1}$ : total concentration, ${ }^{2}$ : extractable concentration; $\mathrm{D} / \mathrm{T}:{ }^{\circ} \mathrm{DTPA} / \mathrm{Total}$ rate $(\%), \mathrm{DF} / \mathrm{T}$ :

'Diphenylcarbazide/Total' rate $(\%) ;{ }^{3}$ : Limit values, mg kg-1 dry wt [26]; ${ }^{4}:[25]$.

\section{B. Variation of Sludge Characteristics According to Sampling Regions}

$\mathrm{pH}, \mathrm{EC}$, organic matter, total $\mathrm{N}$, available $\mathrm{P}$, total $\mathrm{P}$, exchangeable $\mathrm{K}, \mathrm{Ca}$, and $\mathrm{Na}$ contents of sludge; total and available concentrations of $\mathrm{Fe}, \mathrm{Mn}, \mathrm{Cu}, \mathrm{Ni}, \mathrm{Pb}, \mathrm{Cd}$ and $\mathrm{Cr}$ and their relative available ratios were varied considerably with regard to sampling sites. (Table $2 \mathrm{a}$ and Table $2 \mathrm{~b}$ ). The conductivity values determined between $4.28-8.61 \mathrm{dS} \mathrm{m}^{-1}$ in the treatment sludge. This show a significant difference in terms of the conductivity value between the regions and indicate that this is an important criterion to be taken into account in the agricultural use of the sludge. Because one of the major problems in the agricultural use of sludge is the high salt content of sludge in addition to the toxic metals (Topcuoğlu et al, 2003).

While total $\mathrm{Zn}$ content did not show any significant change in sampling regions, available $\mathrm{Zn}$ content and relative available $\mathrm{Zn}$ content showed a significant variation. Although total $\mathrm{Zn}$ content of sludge was determined below the limit values in all regions, it is seen that a very large proportion of total $\mathrm{Zn}$ is in available form. It was emphasized that $\mathrm{Zn}$ was the most mobile metal in the sludge that can cause toxicity in plant development [5].

As can be seen, while sludge of a certain area contain high values of most of the examined criteria, some of other criteria could be included at low levels. This is thought to be due to the fact that the wastewaters that make up the sludge are coming from very variable and complicated sources to the treatment system. The regional differences of parameters determined in the examination sludges are evaluated as the dominance of parameters in the studied wastewater source. Most of the heavy metals in the sludge of Serik region were contained higher levels than the other regions. However, when treatment sludges are evaluated in terms of their heavy metal properties, it is considered that the 'least risk zone sludge' approach can not be applied due to the surprise inlets of wastewater and that the sludge characteristics can not always 
be stabilized locally everytime. This is thought to be due to the fact that the consumption habits of the people of the region, the population density, high and low season of tourism activities and possible industrial wastewater involvement to sewer system.

\section{Seasonal Variation of Sludge Characteristics During the Year}

The highest $\mathrm{pH}$ value of sludge was determined in January, and the lowest $\mathrm{pH}$ value was determined in July and August. It is seen that the $\mathrm{pH}$ values of the treatment sludges that ranged as slightly acid and acid reaction was lowest in summer. Variation of $\mathrm{pH}$ values was about $0.7 \mathrm{pH}$ units during the year, and the seasonal $\mathrm{pH}$ levels of sludges was followed by winter $>$ autumn $>$ spring $>$ summer order (Table 3).

Conductivity values of sludge were determined at the highest level in October and the lowest level in March. When examined at the seasonal level, EC changed as 1.5 fold difference between spring and summer seasons. The lowest organic matter rate was obtained in January, February and March but the highest in July, August and September. Seasonally, it is observed that the rate of organic matter in the treatment sludge was higher in summer and autumn. This difference is presumably due to the change in the population of the region dependent on the change of tourism and or seasonal food consumption.

Table 3. Seasonal variation of some chemical properties and heavy metals of the sludges in Antalya region

\begin{tabular}{|c|c|c|c|c|c|}
\hline & \multicolumn{4}{|c|}{ Sludge Sampling Seasons } & \multirow{2}{*}{ Significancy } \\
\hline & Spring $^{3}$ & Summer ${ }^{4}$ & Autumn ${ }^{4}$ & Winter $^{5}$ & \\
\hline Moisture, \% & 84 & 83 & 81 & 83 & $\mathrm{~ns}$ \\
\hline PH & 6,25 & 6,10 & 6,38 & 6,79 & $* * *$ \\
\hline E.C., $\mathrm{dS} \mathrm{m}^{-1}$ & 5,58 & 6,85 & 8,41 & 6,07 & *** \\
\hline Organic M., \% & 65 & 75 & 74 & 60 & $* * *$ \\
\hline Total N, \% & 5,45 & 6,35 & 5,87 & 4,64 & ** \\
\hline Total P, \% & 1,272 & 1,411 & 1,505 & 0,989 & * \\
\hline Yarayışlı P, \% & 0,145 & 0,194 & 0,181 & 0,134 & ** \\
\hline Exchangeable $\mathrm{K}, \mathrm{mg} \mathrm{kg}^{-1}$ & 2923 & 3558 & 3854 & 1811 & *** \\
\hline Exchangeable $\mathrm{Ca}, \mathrm{mg} \mathrm{kg}^{-1}$ & 5813 & 5991 & 5891 & 5163 & $\mathrm{~ns}$ \\
\hline Exchangeable $\mathrm{Mg}, \mathrm{mg} \mathrm{kg}^{-1}$ & 1381 & 1448 & 1475 & 1578 & $\mathrm{~ns}$ \\
\hline Exchangeable $\mathrm{Na}, \mathrm{mg} \mathrm{kg}^{-1}$ & 782 & 967 & 1789 & 702 & $*$ \\
\hline $\mathrm{Fe}^{1}, \mathrm{mg} \mathrm{kg}^{-1}$ & 13733 & 11533 & 12463 & 16878 & $\mathrm{~ns}$ \\
\hline $\mathrm{Fe}^{2}, \mathrm{mg} \mathrm{kg}^{-1}$ & 835 & 753 & 744 & 875 & $\mathrm{~ns}$ \\
\hline $\mathrm{Fe}, \mathrm{D} / \mathrm{T}, \%$ & 7,4 & 9,9 & 9,5 & 6,0 & $\mathrm{~ns}$ \\
\hline $\mathrm{Mn}^{1}, \mathrm{mg} \mathrm{kg}^{-1}$ & 356 & 286 & 263 & 460 & *** \\
\hline $\mathrm{Mn}^{2}, \mathrm{mg} \mathrm{kg}^{-1}$ & 108 & 97 & 59 & 153 & * \\
\hline $\mathrm{Mn}, \mathrm{D} / \mathrm{T}, \%$ & 26,1 & 28,6 & 22,4 & 29,9 & $\mathrm{~ns}$ \\
\hline $\mathrm{Zn}^{1}, \mathrm{mg} \mathrm{kg}^{-1}$ & 812 & 1023 & 808 & 818 & $\mathrm{~ns}$ \\
\hline $\mathrm{Zn}^{2}, \mathrm{mg} \mathrm{kg}^{-1}$ & 422 & 521 & 525 & 310 & ** \\
\hline $\mathrm{Zn}, \mathrm{D} / \mathrm{T}, \%$ & 50,9 & 61,9 & 64,6 & 37,5 & *** \\
\hline $\mathrm{Cu}^{1}, \mathrm{mg} \mathrm{kg}^{-1}$ & 226 & 186 & 176 & 200 & *** \\
\hline $\mathrm{Cu}^{2}, \mathrm{mg} \mathrm{kg}^{-1}$ & 15,1 & 12,2 & 19,3 & 9,4 & * \\
\hline $\mathrm{Cu}, \mathrm{D} / \mathrm{T}, \%$ & 6,7 & 6,5 & 11,0 & 5,1 & $* *$ \\
\hline $\mathrm{Ni}^{1}, \mathrm{mg} \mathrm{kg}^{-1}$ & 74 & 54 & 48 & 110 & *** \\
\hline $\mathrm{Ni}^{2}, \mathrm{mg} \mathrm{kg}^{-1}$ & 6,26 & 5,74 & 4,87 & 11,54 & *** \\
\hline $\mathrm{Ni}, \mathrm{D} / \mathrm{T}, \%$ & 9,4 & 11,6 & 10,0 & 10,9 & $\mathrm{~ns}$ \\
\hline $\mathrm{Pb}^{1}, \mathrm{mg} \mathrm{kg}^{-1}$ & 410 & 397 & 387 & 421 & ns \\
\hline $\mathrm{Pb}^{2}, \mathrm{mg} \mathrm{kg}^{-1}$ & 8,82 & 9,49 & 8,98 & 8,73 & $\mathrm{~ns}$ \\
\hline $\mathrm{Pb}, \mathrm{D} / \mathrm{T}, \%$ & 2,2 & 2,4 & 2,3 & 2,1 & $\mathrm{~ns}$ \\
\hline $\mathrm{Cd}^{1}, \mathrm{mg} \mathrm{kg}^{-1}$ & 4,84 & 3,70 & 3,38 & 4,90 & $* * *$ \\
\hline $\mathrm{Cd}^{2}, \mathrm{mg} \mathrm{kg}^{-1}$ & 0,26 & 0,27 & 0,27 & 0,20 & $\mathrm{~ns}$ \\
\hline $\mathrm{Cd}, \mathrm{D} / \mathrm{T}, \%$ & 5,5 & 7,5 & 8,9 & 4,0 & ** \\
\hline $\mathrm{Cr}^{1}, \mathrm{mg} \mathrm{kg}^{-1}$ & 41 & 34 & 30 & 47 & **** \\
\hline $\mathrm{Cr}^{2}, \mathrm{mg} \mathrm{kg}^{-1}$ & 0,80 & 0,77 & 0,40 & 0,42 & $* * *$ \\
\hline $\mathrm{Cr}, \mathrm{DF} / \mathrm{T}, \%$ & 2,2 & 2,6 & 16 & 1,0 & $* *$ \\
\hline
\end{tabular}

*: $\mathrm{P}<0.05,{ }^{* *}: \mathrm{P}<0.01,{ }^{* * *}: \mathrm{P}<0.001$. ns: not significant, $\mathrm{D} / \mathrm{T}$ : 'DTPA/Total rate $(\%), \mathrm{DF} / \mathrm{T}$ : 'Diphenylcarbazide/Total' rate (\%) ${ }^{1}$ : total concentration, ${ }^{2}$ : extractable concentration; mean of 27 sampels, ${ }^{4}$ : mean of 30 samples, ${ }^{5}$ : mean of 18 samples.

Total $\mathrm{N}$ content was determined at the highest level in July and August possibly and was determined at the lowest level in January. Seasonally, $\mathrm{N}$ content was determined at the highest level during the summer sludges. The change in seasonal $\mathrm{N}$ content was similar to the change in organic matter content. The change of available $\mathrm{P}$ content with respect to months was not significant, but seasonal change of $\mathrm{P}$ was found to be important. While Total $\mathrm{P}$ content was determined at the 
highest level in the autumn, available $\mathrm{P}$ content was determined at the lowest level in the summer. Total P content was determined at the highest level in May, and was the lowest level in March. Exchangeable $\mathrm{Mg}$ and $\mathrm{Na}$ contents in the sludge did not show any significant change with respect to the month, but $\mathrm{K}$ and $\mathrm{Ca}$ contents showed significant variation. Seasonally, $\mathrm{K}$ and $\mathrm{Na}$ elements showed significant changes while $\mathrm{Ca}$ and $\mathrm{Mg}$ showed no significant changes. $\mathrm{K}$ content was determined at the highest level in September and October, and determined at the lowest level in December and February. Ca content was determined at the highest level in May.

The relative availability of total and available Fe contents in the treatment sludge did not show any significant

change with respect to the monthly and seasonal values. Total Mn content of sludges were determined at the highest level in October, November, December and January. Total and available Mn contents at seasonal level were in the lowest levels in summer and autumn and the highest levels in winter. The total $\mathrm{Zn}$ contents in the sludge did not show any significant difference with respect to the seasonal and monthly changes, and the DTPA-extracteable and relative available $\mathrm{Zn}$ showed significant changes. The highest $\mathrm{Zn}$ content was found in June, and the highest $\mathrm{Zn}$ contents were determined in summer and autumn. Relatively available $\mathrm{Zn}$ was determined at the highest in July. Seasonally the highest $\mathrm{Zn}$ values of sludge were generally determined in summer season.

Total, available and relative available $\mathrm{Cu}$ contents in sludge showed a significant difference with respect to months. Total $\mathrm{Cu}$ content of sludge was determined at the highest levels in March, and available $\mathrm{Cu}$ content was determined at the highest levels in September. Relatively available $\mathrm{Cu}$ was determined at the highest in July. At the seasonal level, the highest total $\mathrm{Cu}$ content was found in the spring and the highest available $\mathrm{Cu}$ content was found in the autumn. Total $\mathrm{Cu}$ content is generally found to be low level in summer and autumn.

Total and available $\mathrm{Ni}$ contents in the treatment sludge showed significant variation with respect to the month. The total and available $\mathrm{Ni}$ contents were determined to be highest in January, and the total and available Ni contents of sludge in the winter season were found to be the highest level, showing a tendency to decrease towards the autumn from the spring.

The total $\mathrm{Cd}$ contents varied significantly according to the month and season, while the available $\mathrm{Cd}$ content did not show any significant change. The relative available $\mathrm{Cd}$ content varied considerably in relation to months and seasons. Total Cd content was determined at the highest level in March and was determined at highest level in spring and winter seasons. The relative available $\mathrm{Cd}$ rate was determined at the lowest level in July, and in fall at seasonal level.

The total $\mathrm{Cr}$ content was determined at the highest level in January and February, while the available $\mathrm{Cr}$ content was determined at the highest level in March. Total $\mathrm{Cr}$ content was determined at the highest level in winter and early spring. In general, total $\mathrm{Cr}$ content tended to decline from spring to autumn.

When the relative availability ratios of heavy metals in sludge are examined, it has been determined that the relative availability ratios of $\mathrm{Cu}, \mathrm{Zn}, \mathrm{Cd}$ and $\mathrm{Cr}$ elements vary considerably in relation to monthly and seasonally. In July, $\mathrm{Zn}, \mathrm{Cu}$ and $\mathrm{Cd}$ elements showed the highest relative availability rate, while $\mathrm{Zn}, \mathrm{Cu}$, and $\mathrm{Cd}$ showed the highest relative availability in the autumn. In general, it is understood that $\mathrm{Cu}, \mathrm{Zn}, \mathrm{Cd}$ and $\mathrm{Cr}$ have decreased in winter and summer when the relative availability rates increased in summer and autumn.

\section{IV.CONCLUSION}

Sludge from various watewater treatment plants located at the coastal regions of Antalya demonsrated significant differences in their physicochemical and agronomic characteristics and heavy metal contents. Most of sludge characteristics and total and available heavy metal contents were significantly changed with regard to seasons. During summer and autumn seasons; low $\mathrm{pH}$ values; high levels of $\mathrm{EC}$, organic matter, total $\mathrm{N}$, total and available $\mathrm{P}$, exchangeable $\mathrm{K}$ and $\mathrm{Na}$, DTPA-extractable $\mathrm{Zn}$ and $\mathrm{Cu}$ contents were determined in the sludge. Generally, $\mathrm{Zn}$ content of sludge was determined at high level in summer and autum, as for $\mathrm{Cu}, \mathrm{Ni}, \mathrm{Pb}, \mathrm{Cd}$ and $\mathrm{Cr}$ elements were found higher in winter and spring. The variation of the sludge characteristics with respect to the sampling areas varied considerably, but no specific region was found in which all the examined criteria were too low or too high.

Findings showed that the treatment sludge composition was changed depending on the region and time. At least one of the parameters in the sludge of a certain region that containing most of parameters at a lower level have determined higher than the other region sludges. Concentrations of heavy metals in sludge have been determined below the maximum permissible limit values. However, the DTPA extractable fraction of heavy metals is quite high in metals such as $\mathrm{Zn}, \mathrm{Ni}$.

Sludge can increase the amount of organic matter and plant nutrients when applied to the soil, but accumulate metal and salt in the soil with a considerable amount of pollutants. Considering the potential harmful effects of heavy metals, beyond the total concentrations, mobility and potential bioavailability of heavy metals in sludge should also be taken into account for the medium and long term effects of sludge application to agricultural soils. Considering the environmental aspects, soil, water and food pollution are thought to be related to the bioavailable fraction of heavy metals in the soil. It is considered that bioavailable metal concentrations and total metal concentrations of soil should be examined together in soil pollution evaluation and setting for soil contamination criteria.

\section{ACKNOWLEDGMENT}

This research was sponsored by TUBITAK (The Scientific and Technological Council of Turkey). Author would like to thank to TUBITAK for the financial support of the project (TOGTAG-2917). 


\section{REFERENCES}

[1] Metcalf E. Wastewater engineering: treatment and reuse. New York, USA: McGraw-Hill; 2003. 1848 pp.

[2] Sommers, L.E. Chemical composition of sewage sludges and analysis of their potential use as fertilizer. J. Environmental Quality, 6:225-232 (1977). https://doi.org/10.2134/jeq1977.00472425000600020026x https://doi.org/10.2134/jeq1977.62225x

[3] Lake DL. Chemical speciation of heavy metals in sewage sludge and related matrices. In: Lester JN, editor. Heavy metals in wastewater and sludge treatment processes: sources, analysis and legislation, vol. 1. USA: CRC Press; 1987. p. 125-53.

[4] Fang M, Wong JWC. Effects of lime amendment on availability of heavy metals and maturation in sewage sludge composting. Environ Pollut 1999;106:83-9.

https://doi.org/10.1016/S0269-7491(99)00056-1

[5] Wong, J.W.C., Fang, K. LI. M., Su, D.C. Toxicity evaluation of sewage sludges in Hong Kong. Environment International, 27, 373-380 (2001). https://doi.org/10.1016/S0160-4120(01)00088-5

[6] García-Delgado, M., Rodríguez-Cruz, M. S., Lorenzo, L. F., Arienzo, M., \& Sánchez-Martín, M. J. (2007). Seasonal and time variability of heavy metal content and of its chemical forms in sewage sludges from different wastewater treatment plants. Science of the Total environment, 382(1), 82-92.

[7] APHA-AWWA-WPCF. Standard methods for the examination of water and wastewater. Washington DC: American Public Health Association; 1989. $1536 \mathrm{pp}$.

[8] Olsen, S.R., Cole, C.V., Watanabe, F.S., Dean, H.C. Estimation of available phosphorus in soils by extraction with sodium bicarbonate. U.S. Department of Agr. Cir. No. 939, Washington D.C (1954).

[9] Pratt, P.F. Methods of soil analysis, Part 2, Chemical and microbiological properties. In Ed. C.A. Black, American Society of Agronomy, Inc. Pub. Agron. Series, No. 9., $\quad$ Madison, Wisconsin, U.S.A. (1965).

[10] ISO 11466 INTERNATIONAL STANDARD. Soil quality-extraction of trace elements soluble in aqua regia. 03-01 (1995).

[11] Lindsay, W.L., Norwell, W.A. Development of a DTPA soil test for zinc, iron, manganese, and copper. Soil Sci. Soc. Am. J., 42:421-428 (1978).

[12] Richards LA. Diagnosis and improvement of saline and alkaline soils, US Salinity Laboratory. Agricultural Handbook No. 60, 1960:160 -71.

[13] Bucher, A.S., Schenk, M.K. Influence of increased salt contents in compost-peat substrates on the phytoavailability of $\mathrm{Cd}, \mathrm{Cu}, \mathrm{Zn}$ and $\mathrm{Mn}$. Gartenbauwissenschaft, 64, 111-117 (1999).

[14] Lopez-Mosquera, M.E., Moiron, C., Carral, E. Use of dairy-industry sludge as fertiliser for grassland in northwest Spain : heavy metal levels in the soil and plants. Resources, Conservation and Recycling, 30, 95-109 (2000). https://doi.org/10.1016/S0921-3449(00)00058-6

[15] Topcuoğlu, B., Önal, M.K., Arı, N. Toprağa uygulanan kentsel arıtma çamurunun domates bitkisine etkisi, I. Bitki besinleri ve ağır metal içerikleri. Akdeniz Üniversitesi Ziraat Fakültesi Dergisi, 16(1): 87-96 (2003).

[16] Williams, D.E., Vilamis, J., Pukite, A.H., Corey, C.E. Metal movement in sludge-amended soils: a nine-year study. Soil Science, 143 (2), 124131 (1987). https://doi.org/10.1097/00010694-198702000-00007

[17] Bragata, G., Leita, L., Figliolia, A., DE Nobili, M. Effects of sewage sludge pre-treatment on microbial biomass and bioavailability of heavy metals. Soil \& Tillage Research, 46, 129-134 (1998). https://doi.org/10.1016/S0167-1987(98)80114-1

[18] Nyamangara, J., Mzezewa, J. The effect of long-term sludge application on $\mathrm{Zn}, \mathrm{Cu}, \mathrm{Ni}$, and $\mathrm{Pb}$ levels in a clay loam soil under pasture grass in Zimbabwe. Agriculture, Ecosystem and Environment, 73, 199-204 (1999). https://doi.org/10.1016/S0167-8809(99)00056-0

[19] USEPA (Environmental Pollution Agency). The use of reclaimed water and sludge in food crop production. National research council. National Academy Press, Washington, D.C. (1996).

[20] Topcuoğlu, B. Effects of repeated applications of sewage sludge and MSW compost on the total and bioavailable heavy metal contents in greenhouse soil. International Soil Congress (ISC) on 'Natural Resource Management for Sustainable Development' June 7-10, 2004 ErzurumTurkey (2004).

[21] Bhogal, A., Nicholson, F.A., Chambers, B.J., Shepherd, M.A. Effects of past sewage sludge additions on heavy metal availability in light textured soils: implication for crop yields and metal uptakes. Environmental Pollution, 121, 413-423 (2003).

[22] Scancar, J., Milacic, R., Strazar, M., Burica, O. Total metal concentrations and partitioning of $\mathrm{Cd}, \mathrm{Cr}, \mathrm{Cu}, \mathrm{Fe}, \mathrm{Ni}$ and $\mathrm{Zn}$ in sewage sludge. The Science of the Total Environment, 250, 9-19, 2000.

[23] Planquart, P., Bonin, G., Prone, A., Massiani, C. Distribution, movement and plant availability of trace metals in soils amended with sewage sludge compost: application to low metal loadings. The Science of the Total Environment, 241, 161-179 (1999). https://doi.org/10.1016/S0048-9697(99)00338-1

[24] Pinamonti, F., Stringari, G., Gasperi, F., Zorzi, G. The use of compost: it's effects on heavy metal levels in soil and plants. Resources, Conservation and Recycling, 21, 129-143 (1997). https://doi.org/10.1016/S0921-3449(97)00032-3

[25] Topcuoğlu, B., Arı, N., Önal, M.K. Korkuteli yöresinde mantar kompost atığının bazı kimyasal özellikleri ve bitki besin içerikleri. Türkiye III. Ulusal Gübre Kongresi, Tarım Sanayi Çevre, 11-13 Ekim 2004, Tokat (2004).

[26] C.E.C. (Council of the European Communities) 1986. Directive of 12 June 1986 on the protection of the environment, and in particular of the soil, when sewage sludge is used in agriculture (86/278/CEE). Official Journal of the European Communities, L181, 6-12. 